\title{
Inhaled frusemide against cold air induced bronchoconstriction in asthmatic children
}

\author{
J Seidenberg, J Dehning, $\mathrm{H}$ von der Hardt
}

\begin{abstract}
Inhaled frusemide prevents bronchoconstriction in asthmatic adults induced by various triggers. To determine if frusemide provides similar protection in children, whether this is age dependent and equally effective for central and peripheral airways, we performed a double blind, placebo controlled, randomised, crossover study on the effect of inhaled frusemide on lung function changes induced by cold air challenge in 21 asthmatic children. In addition, we measured diuresis before and after inhalation. Bronchodilatation after frusemide was not observed. However, deterioration in lung function after frusemide, compared with placebo, was significantly diminished: forced expiratory volume in one second $\left(\mathrm{FEV}_{1}\right)$ was $-5 \cdot 7 \% v-11.5 \%$, peak expiratory flow (PEF) $-7 \cdot 7 \% \quad v-23 \cdot 3 \%$, maximum expiratory flow at $50 \%$ of vital capacity $\left(\mathrm{MEF}_{50 \mathrm{vc}}\right)-16 \cdot 0 \% v-35 \cdot 2 \%$, and at $60 \%$ of total lung capacity (MEF $60 \mathrm{TLC}$ ) $-32.4 \% v-61.6 \%$, and specific airways conduction $-42.0 \% v-57 \cdot 7 \%$, respectively. This effect was not age dependent. Diuresis was significantly increased from a mean (SEM) of 198 (34) $\mathrm{ml} / 3$ hours before inhaled frusemide to $379(62) \mathrm{ml} / 3$ hours after nebulisation. We conclude that inhaled frusemide prevents cold air induced bronchoconstriction in asthmatic children and that increased diuresis can be expected with a dose as low as $28 \mathrm{mg}$ of frusemide given by nebuliser.
\end{abstract}

Recently, the loop diuretic frusemide has regained attention due to its prevention of bronchoconstriction in asthmatic adults if inhaled shortly before various asthmogenic triggers. Bianco and coworkers first reported that inhalation of low doses of frusemide almost completely inhibited the airway obstruction after exercise, ${ }^{1}$ ultrasonically nebulised water, ${ }^{2}$ and various allergens. ${ }^{3-5}$ They demonstrated attenuation of the early and late reaction after allergen challenge, but the reactivity to methacholine improved only during the early response. ${ }^{34}$ However, bronchodilatation was not observed and frusemide failed to protect if given orally or intravenously. ${ }^{15}$

These effects of frusemide, resembling the action of sodium cromoglycate, may provide new insights into the basic mechanisms of asthma. Childhood asthma is different from adult asthma in several respects. We therefore questioned whether inhaled frusemide provides a similar protection in children, whether this is age dependent and equally effective for central and peripheral airways. We chose another indirect stimulus that of hyperventilation of cold air. In addition we measured the diuretic effect of inhaled frusemide, to provide objective data.

\section{Patients and methods}

There were 21 patients (19 boys and two girls) with a mean age of 13.3 (range 8-17) years and mild to moderate asthma who were included in the study after significant bronchial reactivity (decrease in forced expiratory volume in one second $\left(\mathrm{FEV}_{1}\right)>15 \%$ ) could be demonstrated by cold air challenge. All patients were nonsmokers and had been free of respiratory infections for one month before the study. Written informed consent was obtained from their parents. The protocol was approved by the hospital ethics committee.

The study was performed on two separate days at the same time of the day within a week after the screening challenge test. Oral drugs and inhaled sodium cromoglycate were withheld for $\mathbf{2 4}$ hours and other inhalants for at least eight hours before the test. No patient was receiving inhaled or systemic steroids.

Baseline ratios of $\mathrm{FEV}_{1}$ to vital capacity $\left(\mathrm{FEV}_{1} / \mathrm{VC}\right)$ had to be above $75 \%$ of the predicted value and were not allowed to differ more than $15 \%$ between the two study days. The effect of inhaled frusemide was determined by a double blind, placebo controlled, randomised, crossover study.

After measurement of baseline lung function, $28 \mathrm{mg}$ frusemide (Lasix, Hoechst, $10 \mathrm{mg} / \mathrm{ml}$, $\mathrm{pH} 9 \cdot 0,270 \mathrm{mosm} / \mathrm{kg}$ ) or $2.8 \mathrm{ml}$ placebo (physiological saline with sodium hydroxide to reach $\mathrm{pH} 9 \cdot 0,283 \mathrm{mosm} / \mathrm{kg}$ ) was delivered to the patients from a jet nebuliser (Pari-Boy, Medanz) without interruption of the flow for a period of nine minutes. This time period was calculated from the mean (SD) nebulised output of $0.32(0.05) \mathrm{ml} / \mathrm{min}$ measured by weighing before and after inhalation on five occasions. Patients used a mouthpiece and noseclip and were asked to breathe normally.

Pulmonary function tests were repeated within five minutes after nebulisation. This was followed immediately by the cold air challenge to show the maximum protective effect of frusemide. A third lung function test was done 5-10 minutes later. We measured airway resistance (Raw), thoracic gas volume (TGV), and several spirometric values using a volume constant body plethysmography (Bodystar FG 90, Fenyves and Gut) and corrected the results

for body temperature and pressure.
Medizinischen Hochschule 3000 Hannover 61 ,

ederal Republic of Germ 
Table 1 Baseline lung function (mean (SD) \% predicted and range)

\begin{tabular}{|c|c|c|c|}
\hline & Placebo & Frusemide & p Value \\
\hline $\mathrm{FEV}_{1} / \mathrm{VC}$ & $\begin{array}{l}89 \cdot 2(7 \cdot 9) \\
(75 \cdot 0 \text { to } 109 \cdot 0)\end{array}$ & $\begin{array}{l}87.9(6 \cdot 8) \\
(73 \cdot 0 \text { to } 102 \cdot 0)\end{array}$ & $0 \cdot 227$ \\
\hline $\mathrm{FEV}_{1}$ & $\begin{array}{l}85 \cdot 1(11 \cdot 4) \\
(61 \cdot 0 \text { to } 110 \cdot 0)\end{array}$ & $\begin{array}{l}86.1(11 \cdot 7) \\
(63.0 \text { to } 110.0)\end{array}$ & 0.498 \\
\hline PEF & $\begin{array}{l}80.8(8 \cdot 7) \\
(64.0 \text { to } 100 \cdot 0)\end{array}$ & $\begin{array}{l}81 \cdot 2(12 \cdot 4) \\
(65 \cdot 0 \text { to } 105 \cdot 0)\end{array}$ & 0.872 \\
\hline $\mathrm{MEF}_{50 \mathrm{~V} C}$ & $\begin{array}{l}67.7(18 \cdot 4) \\
(43.0 \text { to } 105.0)\end{array}$ & $\begin{array}{l}65.4(15 \cdot 6) \\
(42.0 \text { to } 103.0)\end{array}$ & 0.374 \\
\hline $\mathrm{MEF}_{25 \mathrm{VC}}$ & $\begin{array}{l}55.0(16.9) \\
(30.0 \text { to } 92.0)\end{array}$ & $\begin{array}{l}55 \cdot 2(16 \cdot 7) \\
(33 \cdot 0 \text { to } 100 \cdot 0)\end{array}$ & 0.928 \\
\hline $\mathrm{MEF}_{60 \mathrm{TLC}}$ & $\begin{array}{l}57 \cdot 1(27 \cdot 2) \\
(18 \cdot 0 \text { to } 106 \cdot 0)\end{array}$ & $\begin{array}{l}57 \cdot 7(22 \cdot 6) \\
(15 \cdot 0 \text { to } 101 \cdot 0)\end{array}$ & 0.893 \\
\hline TGV & $\begin{array}{l}137.6(32.7) \\
(83.0 \text { to } 196.0)\end{array}$ & $\begin{array}{l}134 \cdot 1(26 \cdot 2) \\
(92 \cdot 0 \text { to } 187 \cdot 0)\end{array}$ & $0 \cdot 463$ \\
\hline Raw & $\begin{array}{l}95 \cdot 0(40 \cdot 0) \\
(41.0 \text { to } 181 \cdot 0)\end{array}$ & $\begin{array}{l}81.0(38.0) \\
(23.0 \text { to } 179.0)\end{array}$ & 0.038 \\
\hline sGaw & $\begin{array}{l}62.6(13.6) \\
(17.3 \text { to } 135 \cdot 7)\end{array}$ & $\begin{array}{l}72 \cdot 8(32 \cdot 4) \\
(22 \cdot 2 \text { to } 161 \cdot 9)\end{array}$ & 0.062 \\
\hline
\end{tabular}

Table 2 Change in lung function after nebulisation before cold air challenge (mean (SD) \% baseline and range)

\begin{tabular}{|c|c|c|c|}
\hline & Placebo & Frusemide & p Value \\
\hline $\mathrm{FEV}_{1} / \mathrm{VC}$ & $\begin{array}{l}-0.5(3.6) \\
-8.1\end{array}$ & $\begin{array}{c}2.6(2.9) \\
-3.4 \text { ( } 5.2)\end{array}$ & $0 \cdot 106$ \\
\hline $\mathrm{FEV}_{\text {, }}$ & $\begin{array}{c}3.7(4.4) \\
(-3.6 \text { to } 9.8)\end{array}$ & $\begin{array}{c}5.6(2.5) \\
(0.0 \text { to } 7.9)\end{array}$ & 0.335 \\
\hline PEF & $\begin{array}{c}6.3(8 \cdot 4) \\
(-6.3 \text { to } 24 \cdot 1)\end{array}$ & $\begin{array}{c}4.6(5.3) \\
(-2.8 \text { to } 10.8)\end{array}$ & 0.683 \\
\hline MEF $_{\text {sovc }}$ & $\begin{array}{r}3 \cdot 3(11 \cdot 6) \\
(-18.0 \text { to } 23 \cdot 1)\end{array}$ & $\begin{array}{c}10 \cdot 0(13 \cdot 0) \\
(-7 \cdot 3 \text { to } 31 \cdot 5)\end{array}$ & 0.157 \\
\hline $\mathrm{MEF}_{25 \mathrm{VC}}$ & $\begin{array}{r}3.3(10 \cdot 2) \\
(-13.8 \text { to } 22 \cdot 0)\end{array}$ & $\begin{array}{r}9 \cdot 9(15 \cdot 1) \\
(-11 \cdot 1 \text { to } 34 \cdot 3)\end{array}$ & 0.267 \\
\hline MEF $_{\text {GOTLC }}$ & $\begin{aligned} 16.5 & (22 \cdot 1) \\
(-12.5 & \text { to } 51 \cdot 2)\end{aligned}$ & $\begin{array}{l}16.5(22.2) \\
(0.0 \text { to } 68.4)\end{array}$ & 0.373 \\
\hline TGV & $\begin{array}{c}1.9(5.3) \\
(-6.6 \text { to } 10.3)\end{array}$ & $\begin{array}{r}2.5(12 \cdot 2) \\
(-25.7 \text { to } 15 \cdot 1)\end{array}$ & 0.887 \\
\hline Raw & $\begin{array}{c}6.5(49.3) \\
(-55.9 \text { to } 116.4)\end{array}$ & $\begin{array}{c}9 \cdot 1(21 \cdot 0) \\
(-19 \cdot 0 \text { to } 52 \cdot 2)\end{array}$ & 0.893 \\
\hline sGaw & $\begin{array}{l}-11.7(50.0) \\
(-55.2 \text { to } 122.5)\end{array}$ & $\begin{array}{c}-5 \cdot 4(20 \cdot 9) \\
(-39 \cdot 5 \text { to } 24 \cdot 7)\end{array}$ & 0.313 \\
\hline
\end{tabular}

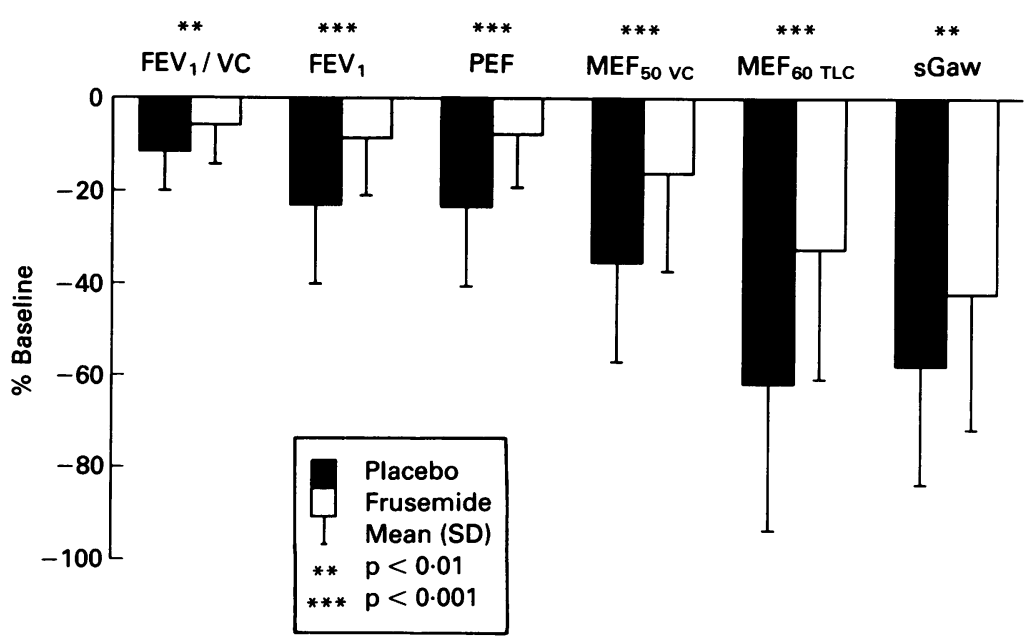

Figure 1 Change in lung function after cold air challenge (expressed as percentage of baseline).

Table 3 Change in lung function after cold air challenge (mean (SD) \% baseline and range)

\begin{tabular}{|c|c|c|c|c|}
\hline & Placebo & Frusemide & p Value & Protection (\%) \\
\hline $\mathrm{FEV}_{\mathbf{l}} / \mathrm{VC}$ & $\begin{aligned}-11.5 & (8 \cdot 5) \\
(1.2 & \text { to }-27 \cdot 2)\end{aligned}$ & $\begin{array}{l}-5 \cdot 7(7 \cdot 5) \\
(7 \cdot 2 \text { to }-25 \cdot 8)\end{array}$ & 0.006 & 50 \\
\hline FEV & $\begin{aligned}-22.9 & (17 \cdot 2) \\
(1.1 & \text { to }-54.5)\end{aligned}$ & $\begin{array}{l}-8 \cdot 5(12 \cdot 3) \\
(12 \cdot 7 \text { to }-42 \cdot 6)\end{array}$ & 0.001 & 63 \\
\hline PEF & $\begin{array}{r}-23.3(17 \cdot 3) \\
(6.6 \text { to }-55 \cdot 8)\end{array}$ & $\begin{array}{l}-7 \cdot 7(11 \cdot 4) \\
(14 \cdot 3 \text { to }-32 \cdot 5)\end{array}$ & 0.001 & 67 \\
\hline $\mathrm{MEF}_{\text {SOve }}$ & $\begin{array}{l}-35 \cdot 2(21 \cdot 7) \\
(-2 \cdot 3 \text { to }-70 \cdot 4)\end{array}$ & $\begin{array}{l}-16.0(21.2) \\
(33.3 \text { to }-60.3)\end{array}$ & 0.006 & 55 \\
\hline $\mathrm{MEF}_{25 \mathrm{VC}}$ & $\begin{array}{r}-33.1(20.0) \\
(5.7 \text { to }-63.3)\end{array}$ & $\begin{aligned}-13.3 & (24.9) \\
(45.5 & \text { to }-64.4)\end{aligned}$ & 0.008 & 60 \\
\hline MEF $_{\text {GOTLC }}$ & $\begin{array}{l}-61.6(30 \cdot 8) \\
(-7.0 \text { to }-100 \cdot 0)\end{array}$ & $\begin{array}{r}-32.4(28.2) \\
(44.1 \text { to }-93.5)\end{array}$ & 0.001 & 47 \\
\hline TGV & $\begin{array}{l}39.6(31.6) \\
(137.1 \text { to }-2 \cdot 7)\end{array}$ & $\begin{array}{l}20.4(17.9) \\
(60.2 \text { to }-11.9)\end{array}$ & 0.003 & 48 \\
\hline Raw & $\begin{array}{l}137.0(159.0) \\
(721 \text { to }-6.5)\end{array}$ & $\begin{array}{l}80.0(74.0) \\
(255 \text { to }-18.0)\end{array}$ & 0.031 & 42 \\
\hline sGaw & $\begin{array}{l}-57.7(25 \cdot 7) \\
(-0.5 \text { to }-92.0)\end{array}$ & $\begin{aligned}-42.0 & (29 \cdot 6) \\
(28.8 & \text { to }-82 \cdot 1)\end{aligned}$ & 0.006 & 27 \\
\hline
\end{tabular}

Cold air challenge was performed after the protocol described by Zach et $a l^{6}$ : the patients hyperventilated $\left(22 \times \mathrm{FEV}_{1}\right)$ subfreezing air $\left(-15\right.$ to $\left.-20^{\circ} \mathrm{C}\right)$ with supplementary $5 \%$ carbon dioxide for four minutes. We used the Respiratory Heat Exchange System (Jaeger) and monitored the patients by pulse oxymetry (Nellcor, Draeger).

Urinary output as well as the fluid intake were monitored during the three hour period before and after nebulisation. Collection was started after emptying the bladder three hours before inhalation and ended again after voluntary voiding just before the inhalation. Measurement was continued separately until three hours after frusemide/placebo inhalation and ended similarly after voluntary micturition. Fluid intake was recorded during both measurement periods.

Statistical analysis was performed using the paired Student's $t$ test. A value of $p<0.05$ was considered significant.

\section{Results}

The difference between baseline lung functions on the two study days was not significantly different except for Raw, which was slightly lower on the day receiving frusemide (table 1 ).

After nebulisation there was a slight increase of spirometric mean values on both study days, but the change in lung function after $28 \mathrm{mg}$ frusemide was not significantly different from that after placebo (table 2).

However, we could demonstrate an evident protective effect of $27 \%-67 \%$ against cold air induced bronchoconstriction after frusemide inhalation in all lung function values after cold air challenge (fig 1, table 3). No statistically significant correlation could be observed between the degree of protection (calculated as the difference in changes of lung function after placebo and frusemide expressed as percentage of the change after placebo) and the degree of baseline lung function impairment (expressed as a percentage of predicted value) or the patient's height, weight, and age. Central airways (reflected by peak expiratory flow (PEF) and Raw measurements), and peripheral airways (shown by TGV and maximum expiratory flow at $25 \%$ of vital capacity) were equally protected. Three of 21 patients showed no protection by frusemide in several lung function parameters but due to the small number no subgroup could be identified. On the other hand, in one patient spirometric values improved after nebulisation of frusemide and the following cold air challenge. However, as specific conductance (sGaw) remained constant, an increase in effort rather than bronchodilatation may have occurred.

Urinary output was significantly increased after inhalation of $28 \mathrm{mg}$ frusemide (fig 2, table 4). We found no significant differences in fluid intake between the two groups nor between measurements taken before and after nebulisation (table 4).

\section{Discussion}

Our results extend the observations of Bianco and coworkers on exercise, water, and allergen 
Table 4 Fluid intake and urinary output during the three hour period before and after nebulisation (mean (SEM) and range)

\begin{tabular}{|c|c|c|c|c|c|c|c|c|}
\hline & \multicolumn{3}{|c|}{ Before nebulisation } & \multicolumn{3}{|c|}{ After nebulisation } & \multirow{2}{*}{\multicolumn{2}{|c|}{$\begin{array}{l}\text { Before/after } \\
\text { comparison ( } p \text { value) }\end{array}$}} \\
\hline & \multirow[t]{2}{*}{ Placebo } & \multirow[t]{2}{*}{ Frusemide } & \multirow[t]{2}{*}{ p Value } & \multirow[t]{2}{*}{ Placebo } & \multirow[t]{2}{*}{ Frusemide } & \multirow{2}{*}{$p$ Value } & & \\
\hline & & & & & & & Placebo & Frusemide \\
\hline $\begin{array}{l}\text { Fluid } \\
\text { intake } \\
\text { (ml/3 hours) }\end{array}$ & $\begin{array}{l}366 \cdot 2(74) \\
(0 \text { to } 1200)\end{array}$ & $\begin{array}{l}296(47) \\
(0 \text { to } 750)\end{array}$ & $0 \cdot 303$ & $\begin{array}{l}309 \cdot 5(60) \\
(0 \text { to } 900)\end{array}$ & $\begin{array}{l}316 \cdot 7(68) \\
(0 \text { to } 900)\end{array}$ & 0.922 & 0.497 & 0.725 \\
\hline $\begin{array}{l}\text { Urinary } \\
\text { output } \\
\text { (ml/3 hours) }\end{array}$ & $\begin{array}{l}165 \cdot 2(24) \\
(50 \text { to } 130)\end{array}$ & $\begin{array}{l}198 \cdot 1(34) \\
(50 \text { to } 800)\end{array}$ & $0 \cdot 183$ & $\begin{array}{l}180 \cdot 7(42) \\
(0 \text { to } 900)\end{array}$ & $\begin{array}{l}378 \cdot 6(62) \\
(100 \text { to } 1400)\end{array}$ & 0.001 & 0.549 & 0.006 \\
\hline
\end{tabular}

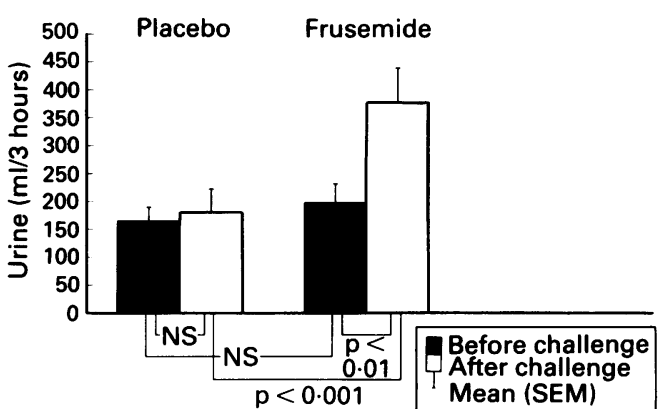

Figure 2 Diuresis during the three hour period before and after nebulisation of placebo or frusemide (expressed as $\mathrm{ml} / 3$ hours).

challenge to another indirect acting stimulushyperventilation of cold air-and also show that children are protected, as are adults, against bronchoconstriction by low doses of inhaled frusemide. This effect was independent of baseline lung function and was not age related. However, the degree of protection for $\mathrm{FEV}_{1}$ was $63 \%$ in our children compared with $29 \%$ recently observed in adults by Grubbe et al. ${ }^{7}$ Their cold air challenge procedure was only slightly different $\left(20 \times \mathrm{FEV}_{1}\right.$ for five minutes) which may suggest less response to frusemide in adulthood. However, differences in the severity of asthma or nebuliser output between the two studies may explain the different results.

In addition, we obtained not only $\mathrm{FEV}_{1}$ but also flow-volume curves, Raw, and TGV. These results show an equal degree of protection after frusemide for central as well as peripheral airways.

As documented in all previous studies, inhaled frusemide did not cause direct bronchodilatation except possibly in one patient. We noticed, however, a slight but similar improvement in many patients after both frusemide and placebo which may be due to the non-physiological $\mathrm{pH}$ of the aerosols. Because frusemide is available in either alkaline or acidic solutions, which by themselves may cause non-specific changes in lung function, ${ }^{8}$ we stress the importance of equalising the $\mathrm{pH}$ of both solutions.

Urinary output was significantly increased after inhaled frusemide. This observation was not mentioned 135910 or was reported not to be present ${ }^{4} 711$ in previous studies, except in one case report. ${ }^{12}$ Objective measurements, however, had not been obtained. Increased diuresis is unlikely to be responsible for the observed bronchoprotective effect, as this effect was found immediately after frusemide inhalation. Nevertheless, the increase in diuresis within three hours indicates a rapid clearance of inhaled frusemide from the epithelial lining fluid. Therefore doses as low as $28 \mathrm{mg}$ of nebulised frusemide may already cause the well known side effects of long term diuretic therapy. The lowest inhaled dose with a bronchoprotective effect may, however, have a negligible diuretic action and should therefore be evaluated.

Besides a possible role for antiasthmatic treatment, the protective effect of inhaled frusemide on various types of challenge may provide new insights in the pathophysiology of asthma. The protection against cold air challenge corresponds to the prevention of bronchoconstriction after other indirect triggers like exercise, ${ }^{1}$ hypo-osmolar stimuli, ${ }^{2}{ }^{9}$ metabisulphite, ${ }^{11}$ adenosine-5' monophosphate, ${ }^{10}$ or allergen inhalation. ${ }^{3}{ }^{4}$ By contrast, direct stimuli like metacholine are less effectively counteracted by inhaled frusemide, ${ }^{3471011}$ suggesting that frusemide does not directly influence smooth muscle contractility. Similarly, cough induced by low chloride solutions is better protected by frusemide than the capsaicin induced cough. ${ }^{12}$ Mast cells, epithelial cells, and neural pathways are more likely targets of frusemide ${ }^{13}$ than smooth muscles. The bronchoconstriction response after hyperventilation of cold air is thought to be mainly due to the rise in osmolarity of the epithelial lining fluid. It still remains to be established whether the airway protection by inhaled frusemide is caused by an effect on chloride channels, the sodiumpotassium-chloride cotransport, the chloridebicarbonate exchange, ${ }^{13} 14$ the release of prostanoids, ${ }^{15}$ or other still unknown factors. The similar action of sodium cromoglycate may help identify the underlying mechanisms.

We conclude that inhaled frusemide is very effective in children in diminishing bronchoconstriction after hyperventilation of cold air. A dose as low as $28 \mathrm{mg}$ does not produce significant bronchodilatation, but causes increased diuresis. Further studies are needed to elucidate the pattern of mediator release after inhaled frusemide to further define the site of action.

We thank Miss Stefanie Heil for skilful technical assistance and the patients for many forced expirations.

1 Bianco S, Vaghi A, Robuschi M, Pasargiklian M. Prevention of exercise-induced bronchoconstriction by inhaled furosemide. Lancet 1988;ii:252-5.

2 Robuschi M, Vaghi A, Gambaro G, Spagnotto S, Bianco S Inhaled furosemide is highly effective in preventing ultrasonically nebulized water (UNH2O) bronchoconstriction. Am Rev Respir Dis 1988;137:412.

3 Bianco S, Pieroni MG, Refini RM, Rottoli L, Sestini P. Protective effect of inhaled furosemide on allergen-induced Protective effect of inhaled furosenide on allergen-induced early and $1069-73$.

4 Verdiani P, Di Carlo S, Baronti A, Bianco S. Effect of inhaled frusemide on the early response to antigen and subsequent frusemide on the early response to antigen and subsequent
change in airway reactivity in atopic patients. Thorax change in airw 
5 Robuschi M, Pieroni MG, Refini M, et al. Prevention of antigen-induced early obstructive reaction by inhaled furosemide in (atopic) subjects with asthma and (actively sensitized) guinea pigs. $\mathcal{f}$ Allergy Clin Immunol 1990;85: sensitioc.

6 Zach M, Polgar G, Kump H, Kroisel P. Cold air challenge of airway hyperreactivity in children: practical application and theoretical aspects. Pediatr Res 1984;18:469-78.

7 Grubbe RE, Hopp R, Dave NK, Brennan B, Bewtra A Townley R. Effect of inhaled furosemide on the bronchia response to metacholine and cold-air hyperventilation changes. I Allergy Clin Immunol 1990;85:881-4.

8 Seidenberg J, Mir Y, von der Hardt H. Hypoxaemia after nebulised salbutamol in wheezy infants: the importance of aerosol acidity. Arch Dis Child 1991;66:672-5.

9 Moscato G, Dellabianca A, Falagiani P, Mistrello G, Rossi G, Rampulla C. Inhaled furosemide prevents both the bronp bronchoconstriction and the increase in neutrophil chemoin asthmatics. Am Rev Respir Dis 1991;143:561-6.
10 Polosa R, Lau LCK, Holgate ST. Inhibition of adenosine 5' monophosphate- and methacholine-induced bronchoconstriction in asthma by inhaled frusemide. Eur Respir $\mathcal{F}$ 1990;3:665-72.

11 Nichol GM, Alton EWFW, Nix A, Geddes DM, Chung F Barnes PJ. Effect of inhaled furosemide on metabisulfiteand metacholine-induced bronchoconstriction and nasa potential difference in asthmatic subjects. Am Rev Respir Dis 1990;142:576-80.

12 Ventresca PG, Nichol GM, Barnes PJ, Chung KF. Inhaled furosemide inhibits cough induced by low chloride conten solutions but not by capsaicin. Am Rev Respir Dis 1990;142:143-6.

13 Anonymous. Inhaled frusemide and asthma [Editorial] Lancet 1990;335:944-6.

14 Boles Ponto LL, Schoenwald RD. Furosemide (frusemide) A pharmacokinetic/pharmakodynamic review (part 1). Clin Pharmacokinet 1990;18:381-408.

15 Pavord ID, Wisniewski A, Tattersfield AE. Inhaled furosemide and exercise-induced asthma. Evidence of a role for inhibitory prostanoids. Am Rev Respir Dis 1991;143:A210.

Asthma paralysis (Hopkins' syndrome)

Since Hopkins first described this syndrome in 10 children in Australia $^{1}$ in 1974 only 12 more cases have been described including a recent report of two children seen in Toronto (Eli $M$ Shahar and colleagues, Pediatrics 1991;88:276-9). Children aged between 13 months and 11 years have been affected, there being 14 boys and eight girls. During recovery from an attack of asthma there is a sudden onset of flaccid paralysis of one or more limbs with no sensory loss but often with muscle pain. In 18 children one limb has been affected, in two both legs, and in the remaining two both limbs on one side of the body. Electrophysiological studies point to acute anterior horn cell disease but poliomyelitis is unlikely as all the children have been previously immunised against that disease. An increase in mainly mononuclear cells in the cerebrospinal fluid has been found in less than half (nine of 21) of the children and a few (three of 21) had a raised protein in the cerebrospinal fluid but not such as to suggest Guillain-Barré syndrome. Enteroviruses (not polio) have been isolated in five of 18 cases. The paralysis is permanent with wasting of the affected limbs.

Where does the asthma come in? As usual with the inexplicable, suggestions abound but the truth is we don't know. It's important to be aware of this connection but unfortunately there seems to be nothing you can do to avoid or mitigate the disaster.

ARCHIVIST

1 Hopkins IJ. A new sydrome: poliomyelitis-like illness associated with actue asthma in childhood. Australian Paediatric fournal 1974;10:273-6. 